\title{
Digital-based instruction: Chances and challenges in English language teaching context
}

\author{
Ningtyas Orilina Argawati ${ }^{1}$, Lilis Suryani ${ }^{2}$ \\ ${ }^{1}$ Graduate School, Universitas Pendidikan Indonesia, Indonesia \\ ${ }^{2}$ English Education Department, IKIP Siliwangi, Indonesia
}

\section{Article Info \\ Article history: \\ Received Mar 10, 2020 \\ Revised Sep 16, 2020 \\ Accepted Oct 13, 2020}

\section{Keywords:}

Chances and challenges

Digital applications

Digital devices

Digital literacy

Digital-based instruction

\begin{abstract}
The use of Digital Based Instruction (DBI) nowadays seems to have many obstacles and difficulties. It is due to lack of digital literacy both lecturers and students. Meanwhile, many advantages also emerge through the use of DBI. It becomes the reason for the lecturers to keep on trying to develop their digital literacy to occupy the need of DBI to their English Language Teaching (ELT) class. This study aimed at revealing the chances and challenges of the implementation of DBI. Descriptive qualitative was employed in this study which involved the use of observation and interview as the instruments. The participants of this study were five English lecturers and 200 students. The findings showed that the chances of applying DBI cover activating students, elevating digital literacy, provoking students' creativity, and creating new application. While some challenges are also emerged. It is due to limited devices and access, and limited digital literacy. The implementation of DBI could provoke the elevation of digital literacy and creativity if we could handle the challenges.
\end{abstract}

This is an open access article under the CC BY-SA license.

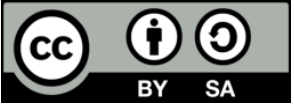

\section{Corresponding Author:}

Lilis Suryani,

English Education Department,

IKIP Siliwangi,

Bandung, West Java, Indonesia.

Email: suryani.lies3@gmail.com

\section{INTRODUCTION}

Digital era has come to our world today. People's way of doing many things such as communicating, getting information, or socializing now shifted into digital ways too. They almost have the digital devices such laptop, smartphone, and tablets [1]. Moreover, the existence of internet supports the change on people on learning, construct, process, and communicate the knowledge they gained [2]. Teaching and learning activities might also be influenced by the development of technology, in this case, digital devices and application. It is as an impact of the industry 4.0 which transform digitally of production or manufacturing based industries. It was driven by connected technologies, namely cyber-physical systems, internet of things, cloud computing and cognitive computing [3, 4].

Many digital devices and application are now available freely to be used by teachers to promote their teaching and learning quality. The inclusion of these digital devices and application on the learning process will encourage students on involving themselves in the activities. Students are usually motivated more if they see something interesting shown through the digital device and application, it is supported by [5] who say students are motivated in learning and they could learn effectively using digital application. There are many kinds of digital applications that can be implemented; one of platforms digital is Kahoot!. Kahoot! is a learning tool that was released in 2013 and it is appropriate for additional references in the learning and 
teaching process $[6,7]$. Kahoot! can also be an interactive learning to encourage students' motivation and create active learning $[8,9]$. It can be seen from previous research that students will be triggered better when they have to answer some questions through Kahoot! if it is compared with when they work on their worksheet. Moreover, they work better on their group when the teacher turned the condition into such a competition than through a regular learning. Another example is ORAI application; it is one application that is easy to use and it is used to encourage students'confident to talk in front of people [10,11]. Based on those explanations, some applications can be used in teaching to enhance the goal of teaching. Nevertheless, the important thing is not only about digital applications but also the teacher's roles in the classroom; it is because they can choose the appropriate application that can be used in teaching and learning process. In other word, the use of technology in teaching process relies on teachers utilize the technology in the classroom.

These possible positive effects give a better sight to the lecturers in teaching in industry 4.0. So, the positive effects can be implemented in one university in Bandung to involve some technologies on their teaching and learning process of English. Through their practices of conducting ELT using some digital devices and application, we could reveal some potentials and challenges faced by those lecturers on cultivating the digital devices and application in the institution. Lecturers could develop their digital literacy to encourage students on developing their digital literacy as well as their creativity towards the use of those devices and application on their learning process. Besides, it is a challenge for the students to seek the learning outcome with regard to the learning management by the lecturer [12].

Digital-based instruction is an instruction using some digital devices and application. On implementing the DBI, teachers need to cultivate their digital literacy in their teaching and learning process $[13,14]$. DBI helps teachers to achieve the objective of learning and teachers should adapt the changing of technology that can be implemented in the classroom. Many studies had been conducted related to the utilization of digital devices in classroom setting [1, 15-18].

Digital devices used by teachers on cultivating their teaching and learning activities involved smartphones, tabs, laptop, and desktop computer [1, 19, 20]. While, [13] considered digital devices and application as a technology which covers LCD projector, laptop computer, digital dictionaries, and software for their presentation. The use of the digital devices and application need digital literacy. Many researchers use various term of digital literacy; one of them is digital competence. Digital competence is needed by both lecturers and students. As specifically defined by [21], digital competence is a skill to utilize technology to gain, manage, and evaluate information, create and share information by using digital tools.

Some studies related to the use of digital devices and application in the ELT classroom had been already conducted. One of them is by [1] which revealed that even though the possession of digital devices of some teachers was high, the use of these digital devices seemed to be far for satisfaction. They had lack of ability on cultivating the devices they had into their teaching and learning process. Another related studies was also conducted by [13] which revealed that teacher in the age of digital-native also had some obstacles on the use of digital devices and application on their teaching activities. In addition, they also found some challenges which come not only from the lecturers but also from the students themselves. The typical study was also done by [22] who finally concluded that most educators are not ready to have made effective use of technology in the stages of appropriation and even invention. There will be a major obstacle if the teachers had a lack competence on operating the technology for ELT [16]. In addition, educators need to know the achievement that can be achieved through technology and the studnets can develop better understandings with digital technology [23].

The previous studies show us that there are some challenges on the implementation of Digital-based instruction in the classroom setting, yet some chances were also widely opened to be developed on this implementation of DBI. Therefore, based on the background of study above the objective of this study was to reveal the chances and challenges which might emerge from the implementation of Digital-Based Instruction in Indonesian context.

In this digital era, teachers and lecturers are hoped to be equipped with sufficient digital devices and application. They need both of them on the implementation of Digital-based instruction. Digital devices meant here are laptops, smartphones, tabs, and desktop computer [1]. While digital applications used cover Edpuzzle, Padlet, Kahoot!, and many more. It is freely accessed and used to the classroom setting. The use of digital devices and application on the implementation of Digital-based instruction needs cultivation of digital literacy both teachers and students. Digital literacy based on [24] is: "The skill to be an effective citizen in the 21 st century, including comprehending the characteristics and features of digital technology and the effect of digital identities, having the ability to manage, comprehend, assess, share and communicate information using digital technology as well as interact in the digital world safely."

Lecturers also are expected to have good digital literacy, efficient utilization of information and communication technology [25], so that they can implement better on using the digital devices and 
application. Lecturers involved in this study were digital-native teachers who were born in 1982-1991 [26]. They have been familiar with the use of technology in their daily life. In that case, instant messaging, text messaging, and blogs characterize the way the digital native communicate [27]. They are used to receive information really fast, like to parallel process and multi-task, and function best when net-worked [28]. By this condition, fortunately, they have the same category as the students they are teaching. This is what makes they feel more comfortable on implementing such a digital application for their teaching activities. From several definition related to some terms above, it can be concluded that digital-based instruction is a way of cultivating digital literacy on the use of digital devices and application towards the teaching and learning process in classroom setting.

\section{RESEARCH METHOD}

A descriptive qualitative was employed in this study. It tried to describe the chances and challenges face by the lecturers in one university in Bandung on conducting teaching and learning activities using some digital devices and application in ELT classroom. It is related to [29] who say that the goal of qualitative descriptive is a comprehensive summarization based on experiences and it can be done individual or a group. The instruments used were observation and interview towards 5 lecturers of English study program who teach English using some digital devices and applications. It was a purposive sampling since the samples were taken purposively based on their way of teaching. The researchers chose five lecturers who teach using digital devices or application only.

The researchers observed five lecturers while they taught in five different subjects such as Innovation in English Language Teaching (ELT), Foundation of English Grammar, Instructional Media, Listening for General Communication, and Speaking for General Communication. The interview was done before and after they performed teaching to know their detail planning and result after teaching, so that they could compare before and after condition related to their opinion towards the use of digital devices and application. In detail, the steps of the research can be seen in Figure 1.

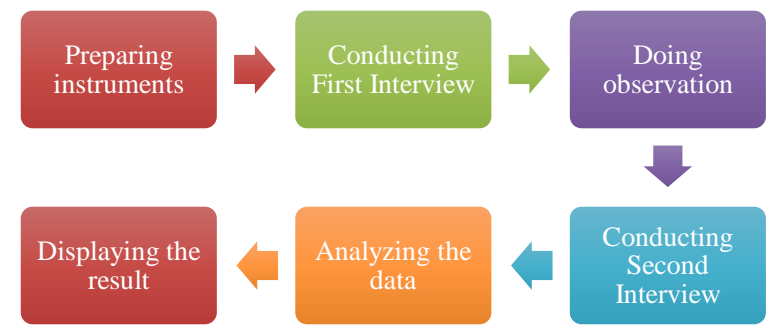

Figure1. Steps of the study

After determining the sample study, the researchers prepared some instrument used on the study. The instruments covered observation and interview. The observation sheet and interview were developed based on two-side sight (both lecturers and students). They covered both lecturers' and students' digital literacy and the condition of the classroom related to the implementation of DBI.

The first interview was done before the teaching and learning process to know the preparation and planning of the lecturers. It deals with their readiness towards some digital devices and application being used. For observation, researchers prepare a sheet containing some points to be observed such as students' readiness, students' attitude towards the instruction done by the lecturers, lecturers' use of digital devices and application. The second interview was done to reveal what happened during the teaching process and to understand the lecturers' opinion towards the implementation of digital-based instruction.

The data gathered through observation and interview were then analyzed and categorized into two main points; chance and challenges on digital-based instruction. The data were finally displayed in the form of descriptive data gathered from those instruments prepared before.

\section{RESULTS AND DISCUSSION}

The result of this study is presented in the form of pictures, tables and result description covering the chances and challenges of the use of Digital-Based Instruction in Classroom context in Indonesia. 


\subsection{Digital devices and application used}

The finding of this study covers two main points; they are the chances of implementing Digitalbased Instruction in classroom and challenges toward it. The lecturers being observed taught in five different classes with five different subjects. On their teaching and learning activities, they used digital devices or application in delivering the material. The digital devices and application used in their teaching can be seen in detail in Table 1.

Table 1. Digital devices and application used by lecturers

\begin{tabular}{clll}
\hline Lecturer & \multicolumn{1}{c}{ Subject } & \multicolumn{1}{c}{ Digital devices } & \multicolumn{1}{c}{ Digital application } \\
\hline 1 & Innovation in ELT & Laptop, in focus, PPT, smartphones & Lecturer's blog \\
2 & Foundation of English Grammar & Laptop, in focus, PPT, smartphones & Lecturer's blog, Kahoot! \\
3 & Instructional Media & Laptop, in focus, PPT, loud speaker, smartphones & Lecturer's blog, Padlet \\
4 & Listening for General Communication & Laptop, in focus, PPT, smartphones & Lecturer's blog, \\
& & & YouTube, Edpuzzle \\
5 & Speaking for General Communication & Smartphones & Orai, Edpuzzle, \\
\hline
\end{tabular}

\subsection{Observation on teaching and learning process}

The researchers came in the classroom to observe how the lecturers used their digital devices and application during the teaching and learning process. Here are some pictures taken from different classes during the observation, Classroom observation can be seen in Figure 2. Based on the observation done by the researchers toward those five lecturers, some result could be obtained as presented in Table 2.
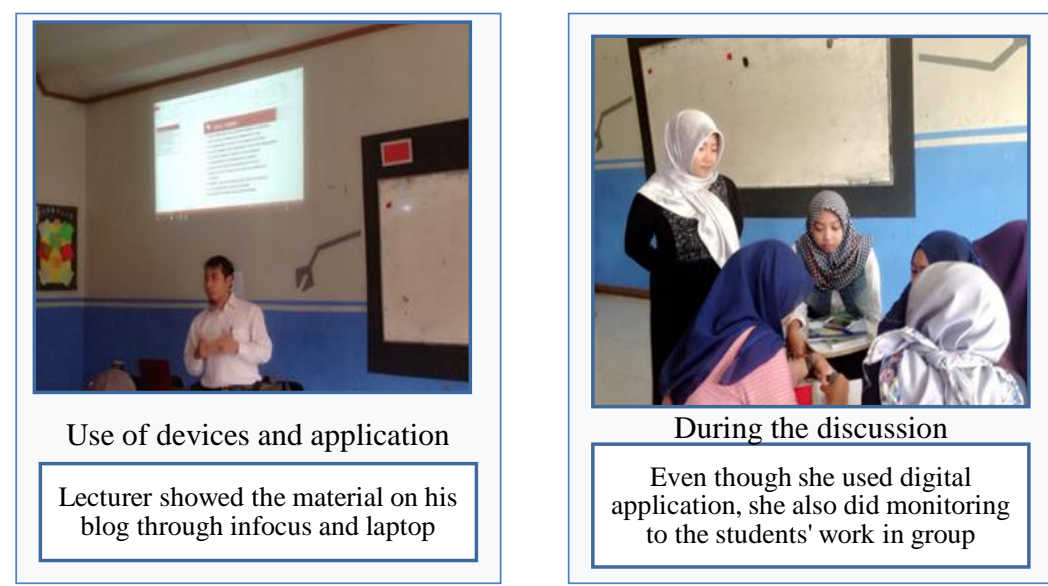

During the discussion

Even though she used digital application, she also did monitoring to the students' work in group

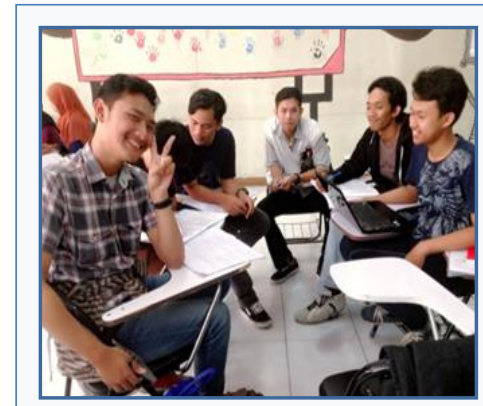

Students' attitude

They enjoyed working with their friends though they only had one laptop

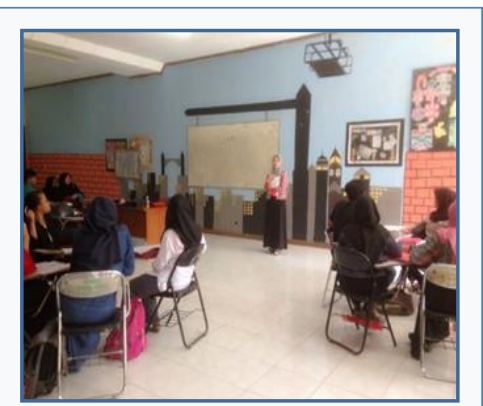

Lecturer's perform in classroom

Students often found difficulties on doing some tasks, so that lecturer always repeated explanation

Figure 2. Classroom observation 


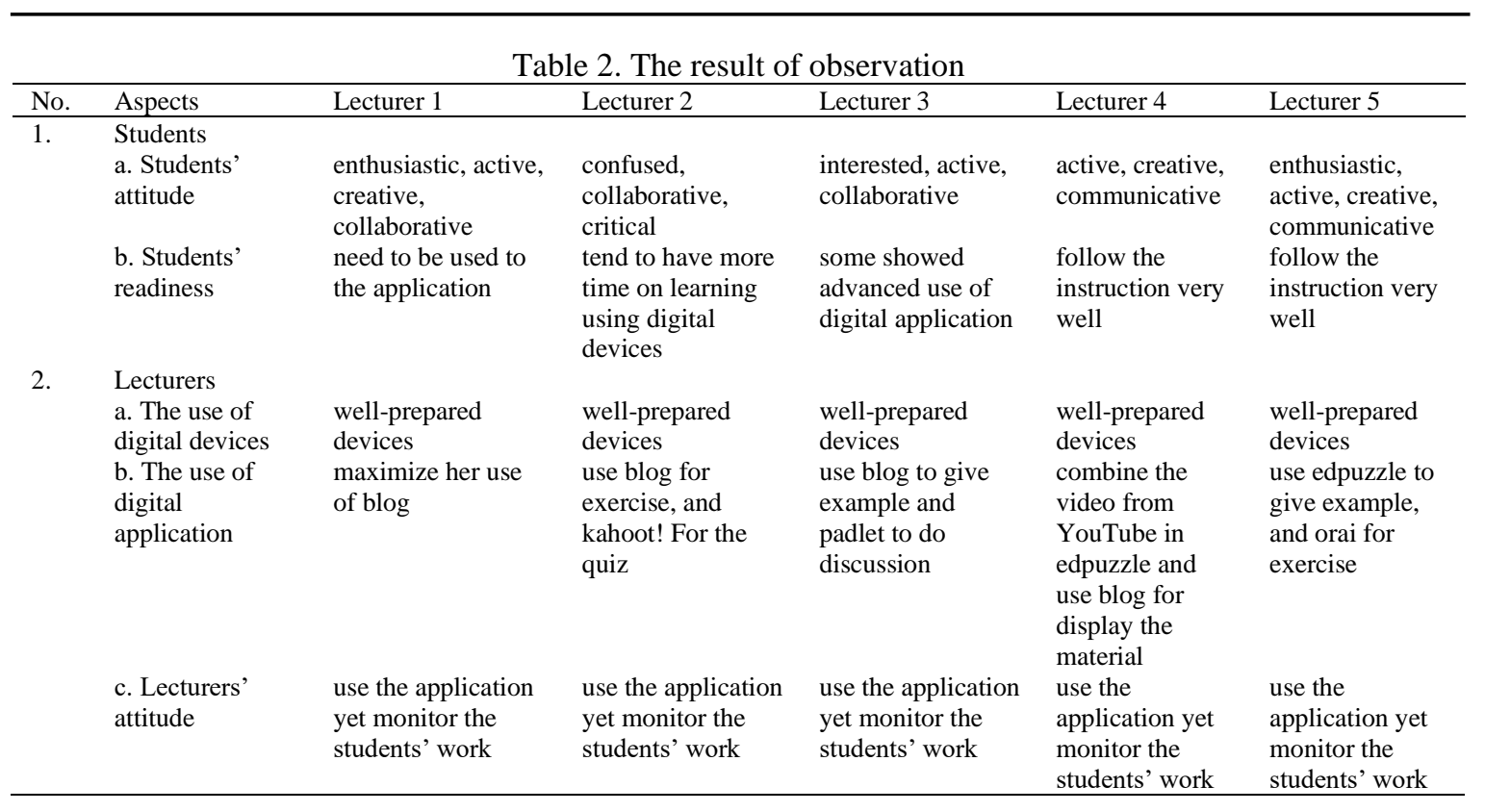

\subsection{Interviews}

The second instrument used in this study was interview which covered two parts. First interview was done before the lecturers did the teaching and learning process as you could see the result in Table 3 . Besides doing the interview before teaching process, the second interview also conducted after the lecturers did the activities in classroom. The teaching process used DGI as well as delivering the material. The result of the second interview could be concluded as shown in Table 4 .

Table 3. The result of the first interview

\begin{tabular}{|c|c|c|c|c|c|c|}
\hline No & Questions & L1 & L2 & L3 & L4 & L5 \\
\hline 1. & $\begin{array}{l}\text { Difficulties on } \\
\text { preparing the } \\
\text { course }\end{array}$ & $\begin{array}{l}\text { Determine which } \\
\text { application to } \\
\text { suit the material } \\
\text { given }\end{array}$ & $\begin{array}{l}\text { Create quiz on } \\
\text { kahoot! }\end{array}$ & $\begin{array}{l}\text { Finding some } \\
\text { examples to be } \\
\text { shown in her blog }\end{array}$ & $\begin{array}{l}\text { Create content } \\
\text { on edpuzzle } \\
\text { containing some } \\
\text { materials taken } \\
\text { from YouTube }\end{array}$ & $\begin{array}{l}\text { Create content on } \\
\text { edpuzzle related } \\
\text { to the material } \\
\text { given }\end{array}$ \\
\hline 2. & $\begin{array}{l}\text { Their expectation } \\
\text { on using digital- } \\
\text { based instruction }\end{array}$ & $\begin{array}{l}\text { students can } \\
\text { learn better using } \\
\text { her blog }\end{array}$ & $\begin{array}{l}\text { students be more } \\
\text { interesting on } \\
\text { complishing the } \\
\text { task through } \\
\text { digital application }\end{array}$ & $\begin{array}{l}\text { students are } \\
\text { interested more on } \\
\text { finding such good } \\
\text { media on teaching }\end{array}$ & $\begin{array}{l}\text { students can } \\
\text { practice listening } \\
\text { better }\end{array}$ & $\begin{array}{l}\text { students } \\
\text { encouraged to } \\
\text { speak more }\end{array}$ \\
\hline
\end{tabular}

Table 4. The result of the second interview

\begin{tabular}{|c|c|c|c|c|c|c|}
\hline No. & Questions & L1 & L2 & L3 & L4 & L5 \\
\hline 1. & $\begin{array}{l}\text { Good things } \\
\text { happened in } \\
\text { class }\end{array}$ & $\begin{array}{l}\text { Students work } \\
\text { collaboratively well } \\
\text { and enjoy learning } \\
\text { from her blog }\end{array}$ & $\begin{array}{l}\text { Kahoot! } \\
\text { Brought joy to } \\
\text { the class }\end{array}$ & $\begin{array}{l}\text { Sufficient to } \\
\text { give them as } \\
\text { many examples } \\
\text { of media as } \\
\text { possible }\end{array}$ & $\begin{array}{l}\text { make the learning } \\
\text { be different in a } \\
\text { positive way }\end{array}$ & $\begin{array}{l}\text { motivate students } \\
\text { even more to } \\
\text { speak up without } \\
\text { hesitation }\end{array}$ \\
\hline 2. & $\begin{array}{l}\text { Challenges on } \\
\text { conducting } \\
\text { DBI }\end{array}$ & $\begin{array}{l}\text { Poor connection, not } \\
\text { all students know } \\
\text { how to do the task }\end{array}$ & $\begin{array}{l}\text { The material } \\
\text { was considered } \\
\text { difficult to the } \\
\text { students, poor } \\
\text { connection }\end{array}$ & $\begin{array}{l}\text { takes much time } \\
\text { on displaying } \\
\text { the media, poor } \\
\text { connection }\end{array}$ & $\begin{array}{l}\text { poor connection, } \\
\text { so that the track } \\
\text { was hard to catch }\end{array}$ & $\begin{array}{l}\text { poor connection, } \\
\text { unsophisticated } \\
\text { devices possessed } \\
\text { by some students }\end{array}$ \\
\hline
\end{tabular}

\subsection{Discussion}

Digital era hits nowadays on our life. It leads us to shift our way of living from manually to be digitally. For instance, it affects our communication and way of sharing information to other. This condition also affects the way of lecturers deliver the material in the classroom in English learning and teaching. The study conducted is aimed at describing the possible chances and challenges may rise by the implementation of Digital-based Instruction. 
The use of Digital-based Instruction in English learning and teaching nowadays becomes a worth applying method to cultivate. That is the main reason of some lecturers to utilize some digital devices and application on their teaching and learning process. The study focused more on revealing the chances and challenges raised from the implementation of Digital-based Instruction. Here is the discussion towards the issues on chances and challenges on DBI implementation based on the result of observation and interviews describe above as presented in Table 5 .

DBI triggers the students to be active, creative and they can have more time to practice using DBI. Overall, it has good implications to learning process and there are many researches related to this finding $[13,30]$. Whereas, the challenges of DBI have to be solved by the lecturers and students in order to support learning process in 4.0 era $[12,31]$.

Table 5. Chances and challenges in ELT context

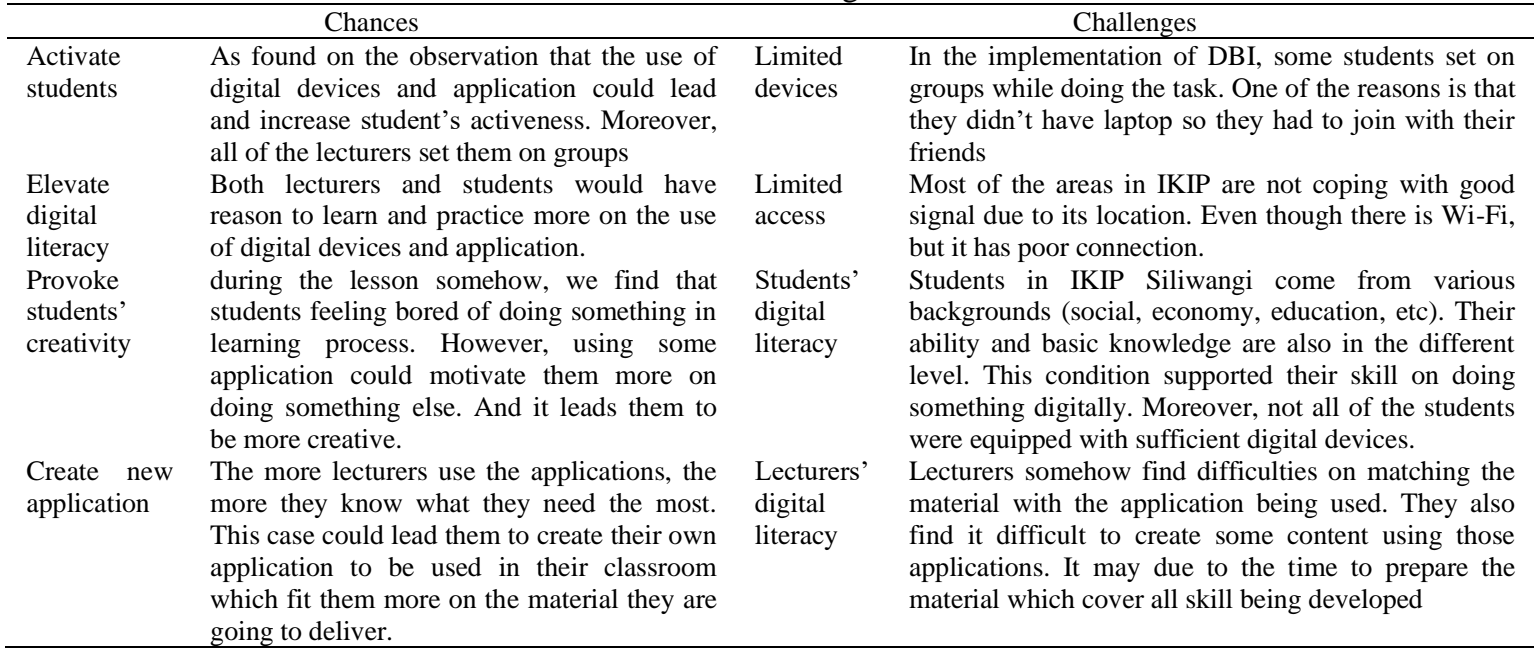

\section{CONCLUSION}

This study is aimed at describing the possible chances and challenges may be faced by lecturers on implementing Digital-based instructions. There are some possible chances and challenges which have been revealed through this study. The chances covered some items related to the improvement of both lecturers and students ability on using digital devices and application, and also develop activeness well as their creativity. While some challenges might also be appear during the study. Limited devices and access are the main challenges which have to be overcome. Moreover, lecturers and students' digital literacy also challenge them to be improved if they want to keep using the Digital-based Instruction. Finally, in this digital era, one has to cultivate and improve their ability on using some digital devices and application so that he or she could elevate the quality of English learning and teaching.

\section{ACKNOWLEDGEMENTS}

Authors would like to thank to all the lecturers and students involved in doing this research. Authors also would like to acknowledge the English education study program of IKIP Siliwangi.

\section{REFERENCES}

[1] Suherdi, D. and Mian, Y., "Towards the establishment of teachers' multicontext information and communication (ICT) training," English language Teaching and Technology Journal, vol. 1, no. 1, pp. 1-11, 2017.

[2] Gialamas, V., Nikolopoulou, K., and Koutromanos G., "Student Teachers' Perception about The Impact of Internet Usage on Their Learning and Job," Computers and Education, vol. 62, pp. 1-7, Mar. 2013.

[3] H. Kagermann, et al., "Recommendations for implementing the strategic initiative INDUSTRIE 4.0," Securing the future of German manufacturing industry, Final report of the Industries 4.0 Working Group, Acatech - National Academy of Science and Engineering, 2013.

[4] P. Gaj, et al., "Computer communication within industrial distributed environment-A survey," IEEE Transactions on Industrial Informatics, vol. 9, no. 1, pp. 182-189, 2012.

[5] Suryani, L., Syahrizal, T., and Fauziah, U. N. E., "Using ORAI application in teaching pronunciation," Indonesian EFL Journal, vol. 5, no. 2, pp. 93-102, 2019. 
[6] Martins, E. R., Geraldes, W. B., Afonseca, U. R., and Gouveia, L. M. B., "Using kahoot as a learning tool," In Ramos I., Quaresma R., Silva P., Oliveira T. (eds), Information Systems for Industry 4.0. Lecture Notes in Information Systems and Organisation, vol. 31. Springer, Cham, 2012.

[7] Putri, A.R. and Muzaki, M.A., "Implementation of Kahoot as a digital game-based learning media in facing the era of the industrial revolution 4.0 (in Bahasa)," Prosiding seminar nasional, 2019, [Online]. Available: http://pgsd.umk.ac.id/files/prosiding/2019/27_Aprilia_Riyana.pdf

[8] Irwan, I., Luthfi, Z. F., and Waldi, "Effectiveness of using Kahoot! to improve student learning outcomes (in Bahasa)," PEDAGOGIA: Jurnal Pendidikan, vol. 8, no. 1, pp. 95-104, 2019.

[9] Plump, C. M., and LaRosa, J., "Using Kahoot! in the classroom to create engagement and active learning: A gamebased technology solution for eLearning novices," Management Teaching Review, vol. 2, no. 2, pp. 151-158, 2017.

[10] Halimah, H., Helmie, J., and Susilawati, N., "Orai application to promote autonomous learning to English learner at senior high school," IJET, vol. 7, no. 2, pp. 110-117, 2018

[11] Saripudin, T., "The Implementation of ORAI application in teaching speaking to senior high school students," Journal of English Pedagogy, Linguistics, Literature, and Teaching (JOEPALLT), vol. 8, no. 1, 2020. [Online]. Available: https://jurnal.unsur.ac.id/jeopallt/article/view/824/695

[12] Puncreobutr, V., "Education 4.0: New Challenge of Learning," Journal of Humanities and Social Sciences, vol. 2, no. 2, pp. 92-97, 2016.

[13] Kurniawati, N., Maolida, E. H., Anjaniputra, A. G., "The praxis of digital literacy in the Efl classroom: digitalimmigrant vs digital-native teacher," Indonesian Journal of Applied Linguistics, vol. 8, no. 1, pp. 28-37, 2018.

[14] Ferrari, A. DIGCOMP: A Framework for developing and understanding digital competence in Europe. Luxembourg: Publications Office of the European Union, 2013.

[15] Nowell, S. D. "Using disruptive technologies to make digital connections: Stories of media use and digital literacy in secondary classrooms," Educational Media International, vol. 51, no. 2, pp. 109-123, 2014.

[16] Young, R., Using Technology Tools in the Public School Classroom. Menomonie, WI: University of WisconsinStout, 2018.

[17] Hobbs, R. "Improvization and strategic risk-taking in informal learning with digital media literacy," Learning, Media and Technology, vol. 38, no. 2, pp. 182-197, 2013.

[18] Park, S., and Burford, S., "A longitudinal study on the uses of mobile tablet devices and chances in digital media literacy of young adults," Educational Media International, vol. 50, no. 4, pp. 266-280, 2013.

[19] Douglas, D., Angel, H., and Bethany, W. "Digital devices, distraction, and student performance: Does in-class cell phone use reduce learning?" Astronomy Education Review, vol. 11, no. 1, pp. 0101081-0101084, 2012.

[20] Sevillano-Garcia, M. L., and Vázquez-Cano, E., "The impact of digital mobile devices in higher education," Journal of Educational Technology \& Society, vol. 18, no. 1, pp. 106-118, 2015.

[21] Hatlevik, O. E., and Chistophersen, K.-A. "Digital competence at the beginning of upper secondary school: identifying factors explaining digital inclusion," Computers \& Education, vol. 63, pp. 240-247, Apr. 2013.

[22] Rein, D., What is effective integration of technology, and does it make a difference? Cupertino, CA: Apple Computer, inc. 2000.

[23] Henderson, M., Selwyn, N., and Aston, R. "What works and why? Student perceptions of 'useful'digital technology in university teaching and learning," Studies in Higher Education, vol. 42, no. 8, pp. 1567-1579, 2015.

[24] Zhang, H. and Zhu, C., "A study of digital media literacy of the 5th and 6th grade primary students in Beijing," Asia-Pacific Education Researcher, vol. 25, no. 4, pp. 579-592. 2016.

[25] Koltay, T., "The media and the literacies: media literacy, information literacy, digital literacy," Media Culture Society, vol. 33, no. 2, pp. 211-221, 2011.

[26] Oblinger, D., and Oblinger, J., "Is it age or IT: First Step toward Understanding the net Generation," in D. Oblinger \& J. Oblinger (Eds.), Educating the Net Generation. Boulder, CO: EDUCAUSE, 2005.

[27] Hartman, J., Moskal, P., and Dziuban, C., "Preparing the academy of today for the learner of tomorrow," in D. Oblinger \& J. Oblinger (Eds.), Educating the Net Generation. Boulder, CO: EDUCAUSE, 2005.

[28] Prensky, M., Digital Natives, Digital Immigrants part 1. On the Horizon, MCB University Press, vol. 9, no. 5, 2001.

[29] Lambert, V. A., and Lambert, C. E., "Qualitative descriptive research: An acceptable desig," Pacific Rim International Journal of Nursing Research, vol. 16, no. 4, pp. 255-256, 2012.

[30] Suherdi, D., Ihrom, S. M., and Nurbiyatun, N., "Incorporating Self-Regulated Learning into English Teaching: Early lessons from the implementation of SMELT I 4.0 DE in an UPI Senior High Lab School class," Proceedings of the 2nd International Conference on Educational Sciences (ICES 2018), vol. 214, pp. 45-49, 2019.

[31] Anggraeni, C. W., "Promoting Education 4.0 in English for Survival Class: What are the Challenges?" Metathesis: Journal of English language, literature, and teaching, vol. 2, no. 1, pp. 12-24, 2018. 